\title{
Women in Leadership in Latin American Regionalism
}

\author{
AndREA Ribeiro HoFFMANN*
}

\begin{abstract}
This paper explores the role of women in leadership in Latin American Regionalism and, more specifically, the incorporation of gender commitments at the Community of Latin American and Caribbean States (CELAC), focusing on the case of the overlapping mandates, during the period 2011-2014, of three women in the Presidencies of Chile, Argentina and Brazil: Michelle Bachelet, Cristina Kirchner, and Dilma Rousseff, respectively. The paper draws on feminist approaches and the literature of women and leadership, and incorporates peculiarities pointed out in the literature of Latin American regionalism, such as weak institutions, presidential diplomacy, and active transnational advocacy networks. The main argument advanced is that the effect of women in leadership cannot be taken for granted as gender was not a priority during the governments of these presidents. The more diffuse commitment to buman rights, which they all shared, as well as their symbolic empowerment effect might have strengthened the gender cause advanced by civil society and transnational advocacy networks.
\end{abstract}

Keywords: Gender, women in leadership, Latin American regionalism, CELAC.

\section{Introduction}

There is a growing literature on gender, women and leadership in individual countries such as the United States and at the global level (Ngunjiril \& Madsen, 2015; Ngunjiri et al., 2015; Tan et al., 2018; Madsen, 2018), but this trend is not matched at the regional level, with the exception of the European Union (EU). EU gender studies include several topics such as gender equality policies (Hoskyns, 1996; Kantola, 2010; Van der Vleuten, 2007, Kantola \& Lombardo, 2017),

\footnotetext{
* Pontifícia Universidade Católica do Rio de Janeiro, Department of International Relations (IRI). ORCID: http://orcid.org/0000-0001-5866-3817
} 
the Europeanization of social (and gender) policy (Falkner, 2007; Sedelmeier, 2009), gendered theories of regionalism (Kronsell, 2012; Hoskins, 2014; Abels, 2014, Kantola, 2010), and women in leadership as well (Claus et al., 2013, Caldeirinha \& Horst, 2017).

Regional organizations in Africa, Asia and Latin America have less norms and policies in the area of social policy in general, and gender; the focus of the existing literature is on the consequences of globalization and trade liberalization for employment, labour conditions, and gender equality, and on how regional social and gender governance should be developed (Van der Vleuten, 2016). In the case of Latin America, the literature about gender at the regional level includes social movements and transnational advocacy networks (Roggeband, 2015), but the topic of women in leadership is also hardly addressed.

Despite almost absence of studies about them, women have not been absent from leadership in the region: for a brief period of time, three major countries in Latin America had, simultaneously, women in power, namely, Chilean President Michelle Bachelet (2006-2010; 2014-2018), Argentinian President Cristina Kirchner (2007-2015), and Brazilian President Dilma Roussef (2011-2016). In 2013, during their overlap period (2011-2014), one recently created regional organization, the Community of Latin American and Caribbean States (CELAC), established gender as one of the eight top priorities in its agenda with relations with the European Union (EU). The main actors influencing such prioritization at the birregional level are transregional advocacy networks; the presence of the three female presidents and their leadership has been pointed out as a possible facilitator, but has not been explored in depth (Ribeiro Hoffmann \& Roggeband, 2017).

This paper explores further the role of the 'Bachelet/Kirchner/Roussef mandates overlap factor' during the period of 2011-2014 to Latin American regionalism and the incorporation if gender commitments in CELAC, drawing on feminist approaches and the relation between women in leadership and policy outcomes (Childs \& Krook, 2008). Next section traces the inclusion of gender commitments in Latin 
American regional institutions, and the third section analyses the case of Bachelet/Kirchner/Roussef mandates overlap.

\section{Gender in Latin American Regionalism}

There are several regional organizations in Latin America, such as the Community of Latin American and Caribbean States (CELAC), the Union of South American Nations (Unasur), the Andean Community (CAN), the Bolivarian Alliance for the Peoples of Our Americas (Alba) and the Southern Common Market (Mercosur). These organizations were created in different historical contexts; the literature on Latin American regionalism distinguishes three main periods. The so-called 'first wave' of regionalism took place during the 1960s, when regional organizations such as the Latin American Free Trade Association (Associação Latino Americana de Livre Comércio - ALALC) and the Andean Pact were created as a means to promote development via the substitution of imports from outside the regional in order to create scale for regional industry, as advanced by the 'dependency theory' approach, developed at the UN regional Economic Commission for Latin America and the Caribbean (Comissão Econômica para a América Latina e o Caribe-CEPAL). The 'second wave' of regionalism evolved in the 1990s, under the influence of neoliberalism; regional organizations' main goal was to promote free trade as the best way to achieve development in a reversal of the previous paradigm. In this context Mercosur was created, and the Andean Pact was reformed into the Andean Community. Finally, after the turn of the century, a new phase evolved, which has been coined as 'post-hegemonic regionalism' when CELAC, Unasur, Alba and the Pacific Alliance were created. In this period, regional organizations embraced different concepts of development and strategies to achieve it. While the Pacific Alliance continued relying on free trade, Unasur and Mercosur promoted the idea of social development, focusing on political inclusion and the adoption of social policies to address what was perceived as the negative effects of neoliberal globalization, and Alba adopted the $21^{\text {st }}$ Century Socialism (Bianculli, 2016). Recent political changes at the domestic level with a return of neoliberal oriented governments in a 
number of countries such as Brazil and Argentina have changed the landscape again, and are have a backlash impact on the institutionalization of social norms and policies (Rigirrozzi \& Tussie, 2017).

During the last decades and along these "waves", most Latin American regional organizations adopted gender norms and policies, and established commitments to be implemented at the domestic level by member-states. In addition, some initiatives were developed to be adopted at the regional level, such as the requirement in Mercosur to gender mainstream external policies and conduct gender impact assessments of free trade policies. Despite the increased levels of institutionalization, most scholars are pessimist about their transformative effects on society. Mercosur gender mainstreaming in trade policy, for instance, was not implemented due to a lack of consensus on methodology (Ribeiro Hoffmann, 2014). Riesco argues that, in the case of the Andean Community, "issues like safety and health in the workplace labour migration, social security and capacity building are discussed but with little consequence $[. .$.$] in most regional organizations social and gender governance$ consists mainly of recommendations and actions plans, and there is no clear trend towards further legalization or strengthening by regional tribunals or complaint mechanisms" (Riesco apud Van der Vleuten, 2016). In short, gender norms in Latin American regionalism have not been key agents for change, especially when compared to local and global levels, or the Inter-American level and the Organization of American States -OAS- (Kook \& True 2012; Friedman, 2009). The literature did not explore the reasons for this weakness but a possible explanation could be that politicians include (gender) norms in regional organizations aiming to accomplish other goals, such as fulfilling expectations by external donors (Borzel et al., 2013). ${ }^{1}$

This leads to the question of leadership, and whether women in leadership might have a positive effect on these processes. When exploring the role of women in leadership in Latin America regionalism, some specificities of this region might be relevant to take into account. A

1 I thank the reviewer for highlighting this point. 
first element is that regional organizations in Latin America have weak institutional frameworks: small secretariats with few international civil servants, and thin mandates, no supranational powers (with the exception of certain features of the Andean Community). Most organizations have regional parliaments, but parliamentarians thereof are mostly not directly elected, they are rather indicated from the national parliaments (Costa et al., 2013, Dri, 2009). In other words, regional organizations are controlled by national governments, as advanced by intergovernmental approaches to regional integration (Rosamond, 2000).

Another characteristic of Latin America regionalism, closely related to the previous, is a phenomenon captured by the concept of 'presidential diplomacy' (Malamud, 2014, 2018). This characteristic refers to the influence that presidents have on the definition of the agenda of foreign policies. In addition to the fact that Latin American regional organizations are purely intergovernmental, i.e. no supranational competencies, members-states' foreign policies are highly influenced by Presidents. Latin American countries have presidential forms of government, and their presidents have a considerable amount of power when compared with parliamentary, party-based regimes. Historically, presidents have often use this power to advance their agenda at the international level, sometimes competing with their ministries of foreign affairs (Malamud, 2014, 2018).

A third characteristic of the region is that it has been fertile ground for the participation of social movements, NGOs and advocacy networks. Several studies on human rights and gender in Latin America focus on the role that these actors have had in specific campaigns and the creation of norms, such as gender and familiar agriculture, violence and women, abortion (Riggirozi \& Tussie, 2012; Sikkink, 2015; Korzeniewicz \& Smith, 2005).

Given the three main characteristics of Latin American regionalism pointed out above, i.e. weak institutional frameworks, presidential diplomacy, and the presence of active civil societies, two promising possibilities to study women in regionalism is to look at the initiatives 
by women in leadership in civil society, or in the presidencies. This paper focuses on the latter. Latin American countries have had few female presidents, however, in the beginning of the $21^{\text {st }}$ Century, for a brief period of time, three key states had women in office, namely, Chilean President Michelle Bachelet (2006-2010; 2014-2018), Argentinian President Cristina Kirchner (2007-2015), and Brazilian President Dilma Roussef (2011-2016). Next section explores to what extent the overlap of mandates has had an impact on the adoption of gender commitments at the regional level, focusing on CELAC.

\section{Women in Leadership: Michelle Bachelet, Cristina Kirchner, Dilma Roussef and the CELAC's Gender Agenda}

What difference do women play while exercising leadership? Was it a "coincidence" that CELAC upgraded gender in its agenda during the period when Bachelet, Kirchner and Roussef were in power? Previous work has pointed out to other factors such as transnational networks in the inclusion of gender commitments in EU-CELAC relations (Ribeiro Hoffmann \& Roggeband, 2017). Literature has not addressed in depth the role of women in leadership; this section advances further in this direction.

Theoretical approaches and empirical research studying the role of women in political leadership vary in their assessment of to what extent one should expect a positive relation between women in leadership and the advancement of gender equality commitments (Childs \& Krook, 2006; Curtin, 2008; Thomas, 2003; Genovese, 1993). By combining the discussion from this literature and the specificities of Latin American Regionalism pointed out in the previous section, such as "presidential diplomacy", this paper explores the role of the "Bachelet, Kirchner, Roussef mandates overlap factor" in the inclusion of gender commitments at CELAC. 


\section{CELACS Gender Agenda}

CELAC was created in 2011 in order to advance political dialogue among countries in Latin America and the Caribbean and cooperation here relies mainly on coordination of policies among member-states; unlike other regional organizations in Latin America, CELAC does not have any specialised body to deal with gender matters. Commitments are often presented in the declarations and action plans are concluded by heads of state and governments following their annual summits, which take place in January. ${ }^{2}$ Before the EU-CELAC summit in 2013, gender equality or women's issues were not relevant to the organisation. In 2013, the final Declaration of the 2013 Summit and Action Plan (2013-2015) list gender as a priority in the bi-regional relations. As analysed by Ribeiro Hoffmann and Roggeband (2017, pp. 174-175):

The 2013 Santiago Declaration refers to gender in three paragraphs. While paragraph 17 calls for a commitment towards gender equality in order to ensure peoples' quality of life, in a similar (broad) framing as previous declarations, paragraph 19 recognises for the first time a relation between gender and investment, and paragraph 38 creates a bi-regional dialogue on gender issues [...] The Santiago Action Plan for 2013-2015 includes gender as one of its eight priorities and establishes a number of precise objectives and a joint work programme which lists dialogue, co-operation activities, and expected results. The three focal points are: i) Political participation of women; ii) Elimination of all forms of violence against women and girls, including sexual violence; and iii) Economic empowerment of women and their participation in the world of work and in all decision-making processes.

In the following year, during the II CELAC Summit, held in Havana, Cuba, January of 2014, a Special Declaration on the "Promotion of Equality and Empowerment of Women in the New Post- 2015

\footnotetext{
2 After the founding summit in Venezuela in 2011, the first CELAC annual summit took place in Santiago, Chile in 2013, the following in Cuba (2014), Costa Rica (2015), Ecuador (2016) and Dominican Republic (2017).
} 
Development Agenda" was announced, calling for continuous work on the three working areas of the Action Plan, and the importance of gender perspectives as a universal element in all actions". During this period of radical change at CELAC, when gender was included as a top priority in the agenda and institutionalized in very precise terms, three CELAC member-states were led by female presidents.

While it is beyond the scope of this article to conduct an in depth process tracing analysis in order to study whether and how the overlap mandate factor matters, the remaining of this section explores in an illustrative manner whether this could have been the case by looking at the political trajectories of Bachelet, Kirchner and Rousself.

\section{Women in Leadership?}

Among the three presidents, Michele Bachelet is who has more consistently addressed gender in her political career. She was born on September 29, 1951, in Santiago, Chile and started studying medicine, but her education was interrupted by the military coup of 1973, when Salvador Allende's regime was overthrown. Her father died in custody in March of 1974 after being tortured, and she was imprisoned in 1975 and held in the torture center at Villa Grimaldi, along with her mother. They managed to go to exile in Australia, where her brother had moved to before, and East Germany, where she continued her education as a pediatrician. She returned to Chile and entered politics after Pinochet was ousted. In 2006 she became Chile's first woman president (Lewis, 2018)

Between her two mandates as president in Chile (2006-2010 and 2014-2018) she has served as the First Executive Director of the United Nations Entity for Gender Equality and Empowerment of Women (UN Women), created in 2010. In an interview in 2012 to the UN News Center she stated how important was her personal experience of being a professional and a mother and having had suffered discrimination herself: 
So I would say that my personal experience as a woman in a country where there were prejudices and stereotypes, of being a woman in a position of power that enabled me to make decisions to fight against gender inequality and support women's empowerment, have given me, on the one hand, the personal experience, but on the other hand, the practical experience of being in power to know what works, what can be done and how no one will do it alone. But building alliances and partnerships with others, we can continue progress. The other thing that has helped me in my current position is having been in a political position [which] helps me to try to think with the head of the one who makes decisions. I think that's essential. We need to work on [creating] an environment in which women's rights are human rights, and that women deserve to be treated respectfully, with dignity and also understanding that, in today's world, we just cannot afford to lose the potential of the half of humanity that are women and girls. Being in politics, you understand how people who make decisions, in politics or in big companies, are pushed by many different interests [...] It's helpful having been there because you understand the problems, but you also try to think of better strategies and better ways to pass on the word (UN News 2012). ${ }^{3}$

In August 2018, shortly after the end of her second mandate, Bachelet was unanimously elected by the UN General Assembly as the new un Office of the High Commissioner for Human Rights (OHCHR). ${ }^{4}$

Such as Bachelet, Cristina Kirchner and Dilma Roussef have both got engaged in politics during the military dictatorships in student's movements. After the democratization, they have included the promotion and protection of human rights as top priorities of their political engagements, but have not addressed gender in particular. That does not mean that they were sensitive to gender only when they were elected; Roussef, for instance, started her inauguration speech in 2011 making reference to her status as a woman:

\footnotetext{
3 http://www.un.org/apps/news/newsmakers.asp?NewsID=73 (accessed 03/05/2017).
}

4 https://www.un.org/press/en/2018/sga1824.doc.htm (accessed 23/09/2018). 
My dear Brazilians: By the sovereign decision of the people, today will be the first time that the presidential sash encircles the shoulders of a woman. I am immensely honored by this choice the Brazilian people have made, and I recognize the historic significance of this decision. I also recognize that the green and yellow silk of the presidential sash may appear to be soft, but it carries with it an enormous responsibility for the nation. To take on this responsibility, I have with me the strength and the example of the Brazilian woman. I open my heart to receive, at this moment, a spark of her immense energy. And I know that my presidential term must involve the most generous interpretation of this brave vote that the people have made: after electing a man of the people, of the working class, to the presidency, they have decided to call on a woman to take the helm in the country's destiny. I am here to open doors so that in the future many other women can also be presidents; so that, today, all Brazilian women may feel proud and happy to be themselves. I am not here to boast of my own life story, but rather to praise the life of every Brazilian woman. My greatest commitment, I repeat, is to honouring our women, protecting our most vulnerable people, and governing for everyone. (Roussef, 2011). ${ }^{5}$

It is not clear whether Rousseff adopted a discourse on gender for instrumental reasons, but when she was ousted of power in a highly controversial impeachment in 2016, the gender question did not pass unnoticed, as well as in the succession of Kirchner: "In Brazil, the new president, Michel Temer, who appointed a cabinet devoid of women, is married to a former beauty pageant contestant. Juliana Awada, the wife of President Mauricio Macri of Argentina, is a fashion designer. And Isabel Macedo, the new fiancée of Juan Manuel Urtubey, a prominent Argentine governor with presidential ambitions, has been an actress in soap operas, as has Angélica Rivera, the first lady in Mexico". According to Sergio Berensztein, a prominent Argentine political commentator: “It's a manifestation of

\footnotetext{
5 The official English transcript of Rousseff's full speech, as released by Brazil's Ministry of External Relations. Retrieved from https://www.huffingtonpost.com/2011/01/03/ dilma-rousseff-inaugurati_1_n_803450.html (access 03/05/2017).
} 
residual macho attitudes". ${ }^{6}$ Feminist movements and women went to the streets to express solidarity with Rousseff: "New movements, such as Mulheres Pela Democracia (Women for Democracy), have sprung up in support as women have marched in protest and even sent Rousseff letters and pictures empathizing with the injustice of her ousting, and warning of its future implications".?

\section{Concluding Remarks}

This paper has explored the role of the "Bachelet/Kirchner/Roussef mandates ovelap factor" during the period of 2011-2014 in Latin American regionalism and the incorporation of gender commitments in CELAC, drawing on the feminist argument about the impact of women in leadership on policy outcomes. The conducted analysis suggests that the effect of these presidents was less due to a targeted policy strategy, but rather to subtler reasons. The three presidents were politically engaged during the military dictatorships in their own countries, and had suffered direct violence in this period, a fact that led them to pursue the promotion of human rights in their political trajectories. Gender was not a top priority nor systematically addressed in their governments, but because of being women an expectation for them to refer to gender was raised. Transnational advocacy networks pointed out in the secondary literature as key driving forces for the inclusion of gender commitments at CELAC, might have been inspired and empowered by the presidents. While the analysis developed in this paper only illustrates the argument advanced, it brings into attention the need to conduct more research on the role of women in leadership in Latin American regionalism. In addition to the role of presidents, the role of other women such as those working on regional secretariats, regional parliaments as well as in the national and transregional government and civil society should be explored.

\footnotetext{
6 Retrieved from https://www.nytimes.com/2016/05/15/world/americas/dilma-rousseff-michelle-bachelet-cristina-fernandez-de-kirchner.html (access 23/09/2018).

7 Retrieved from https://www.theguardian.com/global-development/2016/jul/05/ in-brazil-women-are-fighting-against-the-sexist-impeachment-of-dilma-rousseff (accessed 23/09/2018).
} 


\section{References}

Abels, G. (2014). Gendering European Integration Theory. Opladen: Barbara Budrich Publishers.

Bianculli, A. (2016). Latin American regionalism. In T. Borzel \& T. Risse (Eds.), The Oxford handbook of comparative regionalism (pp. 154-177). Oxford: Oxford University Press.

Börzel, T., Van Hüllen, V. \& Lohaus, M. (2013). Governance transfer by regional organizations. Patching Together a Global Script. Basingstoke: Palgrave Macmillan.

Caldeirinha, C. \& Horst, C. (2017). Women leading the way in Brussels. London: John Harper Publishing.

Childs, S. \& Krooks, M. L. (2006). Should feminists give up on critical mass? A contingent yes. Politics and Gender, 2(4), 522-530. Doi: https://doi. org/10.1017/S1743923X06251146

Claus, V. A., Callahan, J. \& Sandlin, J. R. (2013). Culture and leadership: Women in nonprofit and for-profit leadership positions within the European Union. Human Resource Development International, 16(3), 330345. Doi: https://doi.org/10.1080/13678868.2013.792489

Costa, O., Dri, C., Stavridis, S. (Eds.). (2013). Parliamentary dimensions of regionalization and globalization: the role of inter-parliamentary institutions. Berlin: Springer.

Debusser, P. (2012). Gender mainstreaming in EU development policy towards LA: Transforming gender relations of confirming hierarchies? Latin American Perspectives, 39(6), 181-197. Doi: https://doi. org/10.1177/0094582X12458423

Dri, C. (2009). At what point does a legislature become institutionalized? The Mercosur parliament's path. Brazilian Political Science Review, 3(2), 60-97.

Friedman, E. J. (2009). Re(gion)alizing women's human rights in Latin America. Politics \& Gender, 5, 349-375. Doi: https://doi.org/10.1017/ S1743923X09990171

Genovese, M. A. (Ed.). (1993). Women as national leaders. Newcastle: Sage Group. Hoskyns, C. (2004). Gender perspectives. In A. Wiener \& T. Diez (Eds.), European Integration Theory. Oxford: Oxford University Press.

Kantola, J. (2010). Gender and the European Union. Basingstoke: Palgrave Macmillan.

Kantola, J. \& Lombardo, E. (Eds.). (2017). Gender and the economic crisis in Europe: Politics, institutions and intersectionality. Berlin: Springer. 
Korzeniewicz, R. P. \& Smith, W. (2005). Transnational civil society actors and regional governance in the Americas: Elite projects and collective action from below. In L. Fawcett \& M. Serrano (Eds.), Regionalism and governance in the Americas (pp. 135-157). Basingstoke: Palgrave.

Kronsell, A. (2012). 'Gendering theories of European integration. In G. Abels \& J. Mushaben (Eds.), Gendering the European Union. New approaches to old democratic deficits (pp. 23-40). Basingstoke: Palgrave Macmillan.

Krook, M. L., Mackay, F. (Eds.). (2011). Gender, politics and institutions: Towards a feminist institutionalism. Basingstoke: Palgrave Macmillan.

Krook, M., True, J. (2012). Rethinking the life cycles of international norms: The United Nations and the global promotion of gender equality. European Journal of International Relations, 18, 1103-127. Doi: https:// doi.org/10.1177/1354066110380963

Lewis, J. J. (2018). Michelle Bachelet. ThoughtCo, Jun. 14, 2018, thoughtco.com/ michelle-bachelet-3529298

Liebert, U. (Ed.) (2003). Gendering Europeanisation. Frankfurt: Peter Lang.

Mackay, F. et al. (2009). The feminist potential of sociological institutionalism. Politics and Gender, 5(2), 253-262. Doi: https://doi.org/10.1017/ S1743923X09000208

Mackay, F., Kenny \& Chappell L. (2010). New institutionalism through a gender lens: Towards a feminist institutionalism? International Political Science Review, 31(5), 573-588. https://doi.org/10.1177/0192512110388788

Madsen, S. R. (Ed.). (2018). Handbook of research on gender and leadership. Cheltenham: Edward Elgar Pub.

Malamud, A. (2014). Presidentialist decision making in Latin American foreign policy: examples from regional integration processes. In J. I. Dominguez \& A. Covarrubias (Eds.), Routledge handbook of Latin America in the world (pp. 112-123). Abingdon: Routledge.

Malamud, A. (2016). Presidentialism and Mercosur: A hidden cause for a successful experience. In F. Lauresen (Ed.), Comparative regional integration: Theoretical perspectives (pp. 53-74). Abingdon: Rutledge.

Ngunjiri, F. W. \& Madsen, S. R. (Eds.). (2015). Women as global leaders. Charlotte: Information Age Publishing.

Ngunjiri, F. W., Longman, K. A. \& Cherrey, C. A. R. Madsen (Eds.). (2015). Women and leadership around the world. Charlotte: Information Age Publishing. 
Ribeiro Hoffmann, A. (2014). Gender mainstreaming in Mercosur and Mercosur-EU trade relations. In: A. van der Vleuten, C. Roggeband \& A. Eerdewijk (Eds.), Gender equality norms in regional governance: Transnational dynamics in Europe, South America and Southern Africa (pp. 117-138). Basingstoke: Palgrave McMillan.

Ribeiro Hoffmann, A. \& Roggeband, C. (2017). 'Gendering EU-Latin America Inter-regional relations'. In T. Kruesssmann \& A. Ziegerhofer (Org.), Promoting gender equality abroad. An assessment of EU action in the external dimension (pp. 163-189). Frankfurt: LIT Verlag.

Riggirozzi, P. \& Tussie, D. (2017). Rethinking our region in a post-hegemonic moment. In J. Briceno Ruiz, I. Morales, (Eds.), Post-hegemonic regionalism in the Americas. Towards a Pacific vs. Atlantic divide, (pp.16-31). London and New York: Routledge.

Roggeband, A. (2015). Latin American advocacy on violence against women and the OAS Convention. In A. van der Vleuten \& A. van Eerdewijk (Eds.), Mapping gender norm dynamics. Gender, regions and norms: Debunking Eurocentrism (pp. 139-164). Basingstoke: Palgrave Mcmillan.

Rosamond, B. (2000). Theories of European integration. New York: St. Martin's Press.

Sikkink, K. (2015). El papel protagonista de Latinoamérica en los derechos humanos. Sur Jornal, 22.

Tan, S. J. \& DeFrank-Cole, L. (Eds.). (2018). Women's leadership journeys: Stories, research, and novel perspectives. Abingdon: Routledge.

Thomas, S. (2003). The impact of women in political leadership positions. In S. Carroll (Ed.), Women and American politics. New questions, new directions (pp. 87-110). Oxford: Oxford University Press.

Tickener, J. A. (2002). Feminist perspectives on international relations. In W. Carlsnaes, T. Risse \& B. Simmons (Eds.), Handbook of international relations (pp. 275-291). Newcastle: Sage Group.

Van der Vleuten, A. (2007). The price of gender equality. Member states and governance in the European Union. Aldershot: Ashgate.

Van der Vleuten, A. (2016). Social and gender governance. In Borzel \& T. Risse (Eds.), The Oxford handbook of comparative regionalism (pp. 405-429). Oxford: Oxford University Press.

Zippel, K. (2004). Transnational advocacy networks and policy cycles in the EU: The case of sexual harassment. Social Policy, 11(1), 57-85. Doi: https://doi.org/10.1093/sp/jxh026 